\title{
Discurso pronunciado por el Primer Ministro de Nueva Zelandia Right Hon. John Key, MP
}

号

8 de marzo de 2013 en el acto organizado por Icare, la Fundación Chilena del Pacífico y el Instituto Libertady Desarrollo, con el patrocinio de la embajada de Nueva Zelandia y el Ministerio de Relaciones Exteriores de Chile

Ladies and Gentlemen, it's great to be here in Santiago. I would like to thank the organisers of this event for the work you do in developing trade relations, and in helping our countries get to know each other better.

During my time here I'm looking forward to trying two things Chile is famous for - your delicious beef and a pisco sour.

I am going to Puerto Montt tomorrow to see Fonterra's longest-standing overseas investment, a Soprole [So-pro-lay] dairy farm, and I hope both will be on the menu at the barbecue there.

It will also be fantastic to see some of the beautiful countryside Chile has to offer.

Ladies and Gentlemen, New Zealand's relationship with Chile is our longest-standing in Latin America.

We both opened embassies in each other's countries in 1972 and, ever since, we have forged strong bonds across a number of different fields.

Relations between New Zealand and Chile are in great shape, and I enjoy a warm relationship with President Piñera. 
Our most recent meeting was at APEC in Vladivostok last September, and it was a good opportunity to reflect on the vibrant nature of our countries' relationship in recent times.

We also had the opportunity to discuss the future, and the potential for Chile and New Zealand to do more together.

A great deal of that requires political leadership, and our governments are committed to working together in a number of areas.

But the real energy will come from the private sector, particularly through collaboration in education, increased trade and investment, and business partnerships.

The relationship between New Zealand and Chile is broad and wide-reaching.

Our two countries work closely together in agriculture, the geothermal energy sector and in education.

Companies like Fonterra are well-established here. Trading as Soprole, it's the second-most recognised brand in Chile after Coca-Cola.

And Mighty River Power has a number of geothermal investments in Chile.

We have a free trade agreement, through the P4, and I'll talk about more about that shortly.

We have a shared interest in Antarctica, where I was privileged to visit earlier this year to view New Zealand's environmental research and preservation work.

As agricultural nations and suppliers of food to the world, New Zealand and Chile have been key partners in the Global Research Alliance.

Our relationship in this field is also complemented by our collaboration on the FONTAGRO project on greenhouse gases.

Almost all of New Zealand's universities have cooperation agreements with Chilean counterparts.

Tomorrow I'm looking forward to meeting young Chileans who have studied in New Zealand and brought new skills back to their home country.

Can I just add that the only direct air link between Latin America and New Zealand runs from here to Auckland, so I encourage you to make the most of it and visit our country, enjoy the scenery and try some of our award-winning wine. 


\section{TRADE}

The Asia-Pacific region is our shared home. Our economic prosperity relies on strong trading relationships with other Asia-Pacific countries.

In recent years, both Chile and New Zealand have worked to break down barriers to international trade and investment, whether in partnership at the WTO, through APEC, or in the pursuit of more liberal and open markets through free trade agreements.

We both have achieved considerable success.

New Zealand and Chile remain the only two OECD countries to have FTAs with China.

Our FTA with China has been hugely successful. Since 2008 , our exports to that country have trebled. China is now our second largest export market, after Australia and ahead of the USA, and it's now our largest source of imports.

New Zealand, and our ASEAN partners, are starting to see the benefits of the Australia-ASEAN-NZ FTA concluded in 2009 .

We're benefiting from more and more people rising out of poverty, having a better standard of living, and wanting to eat better, more nutritious food, particularly protein.

As efficient producers of top-quality and safe food, New Zealand and Chile are well placed to meet that demand.

The results we've achieved are significant in their own right. But the world is not standing still.

Countries with many years of experience negotiating FTAs are now looking beyond bilateralism.

The focus has become more strategic - to develop deeper, more inter-connected partnerships.

Chile and New Zealand can claim to be at the forefront of that effort.

It was over a decade ago that we agreed with Singapore to negotiate the Pacific Three - or 'P3' - partnership.

It was not long before Brunei joined and we had concluded the Trans-Pacific Strategic Economic Partnership. 'P4', as it became known, was the first ever multi-party FTA that connected the Americas, the Pacific and Asia. 
That FTA has laid the platform for the Trans Pacific Partnership negotiations.

These now include the US, Australia, Peru and Viet Nam, Malaysia, and most recently Mexico and Canada.

We are now 11 economies, representing US\$21 trillion in GDP and 600 million consumers.

TPP has strong momentum.

It could fundamentally reshape the trade and investment landscape across the Asia-Pacific.

The TPP is also complementary to other trade relationships in the region.

Chile is a founding member of the Pacific Alliance, to which New Zealand has observer status. This group - comprising Chile, Colombia, Mexico and Peru - represents around 35 per cent of Latin American GDP.

Our observer status with the Pacific Alliance gives New Zealand another opportunity to build links with like-minded Latin American countries.

New Zealand is also participating in the Regional Comprehensive Economic Partnership negotiations, comprising the ASEAN nations and six others, launched in November.

However, the TPP remains the most advanced and ambitious trade negotiation in the Asia-Pacific, and it offers a glittering prize.

Negotiations have been on-going for almost three years and leaders have committed to concluding an agreement by October.

It is critical TPP achieves the high-quality goals that have been set.

Both our countries know we get the most benefit from trade and economic connections when we tackle trade protectionism in a comprehensive way.

For example, Chile and New Zealand have worked as partners in the World Wine Trade Group to develop international wine regulations to ensure our world-class 'New World' wines don't get unfairly closed out of the European market through trade-restricting regulations.

TPP is no different.

A truly regional agreement requires clear commitments that apply to trade wherever a trader is based in the TPP region. 
The result over time will be to simplify all the different preferential trade rules that exist among TPP members now.

We are also trying to progress aspects of TPP to help facilitate regional supply chains, competitiveness and good regulatory practice. It's no secret this is challenging.

Some of these issues have never been progressed in an FTA before.

Any negotiation is a complex process and time is needed to get the substance right.

\section{Benefits for NZ AND Chile}

But the benefits from TPP for the region would be significant. The latest estimates suggest that a successfully concluded TPP between the current 11 members could be worth as much US $\$ 200$ billion in exports for the region.

Gains to Chile are estimated at a US $\$ 3.1$ billion increase to exports, and economic welfare gains of US\$2 billion.

Estimates for New Zealand suggest smaller export gains from TPP but a larger GDP effect.

These numbers are significant by anyone's measure, particularly in a global economic environment where growth is hard work.

A successful TPP would lift the competitiveness and productivity of our economies, and bring more trade, jobs, innovation and economic growth to the region.

It also means more opportunities for collaboration between our two countries.

A large part of the value we offer each other is strategic.

New Zealand is fully connected to Asia, with daily flights to a number of cities in the region. We have regular shipping connections to Asian ports. We also have a network of free trade agreements with Asian economies to facilitate trade and investment throughout the region.

This is part of what New Zealand offers Chile - we are a safe, business-friendly base for your businesses wanting to expand into the Asia-Pacific.

And Chile is a launch pad for New Zealand companies into Latin America. 
The target of concluding negotiations by October is an ambitious one, but achievable.

We know that others in the region are watching our progress closely, with some carefully considering if they, too, should seek to join TPP.

The conclusion of an open, inclusive agreement would further heighten interest. If others can join us in meeting the ambition we have, we would welcome them to the TPP fold.

Ladies and Gentlemen.

New Zealand continues to have a warm and friendly relationship with Chile.

We share a similar outlook on the world - we are both countries with strong primary industries, we are competitive producers and we are ardent supporters of trade liberalisation.

We cooperate on regional and global issues together.

That cooperation is set to continue. As more and more countries become wealthier, the demand for the type of food they want is changing.

Our biggest challenge is being able to work together with other countries to ensure that we can provide enough clean, safe food to keep the world fed.

Thank you, gracias. 